\title{
Reference Theory: Situation Hopeless But Not Impossible
}

\begin{abstract}
After summarizing the historical background of reference theory, the author describes the neglect of reference theory by reference librarians and the library profession in general through analysis of periodical literature 1954-1964. The survey reveals: (1) some consensus on the nature of reference; (2) consistent emphasis on articles describing specific reference operations; and (3) absence of articles discussing theory. Virtually unnoticed by librarians is the growing movement among researchers in areas other than librarianship to study general processes of information use and exchange.
\end{abstract}

$\mathbf{I}_{\mathrm{T}}$ T IS PROBABLY not without justification that librarians are often reminded of Emerson's admonition that "a foolish consistency is the hobgoblin of little minds." The burden of this message might be particularly applicable to the spectrum of our writings on the subject of reference services. The existing situation was well summarized in an editorial in Library Journal.

... it is a curious anomaly that reference work, which so many librarians regard as the highest form of library service, should remain the most ill-defined and poorly recorded area of our work and service. $^{1}$

From history we know that reference service was not the traditional function of the library. It began in the late eighteen hundreds with the public library's desire to justify its tax basis. In historical sketches we quite frequently refer to

1 "Future Directions in Reference Service," Library Journal, LXXXV (April 15, 1960), 1540.

$\mathrm{Mr}$. Wynar is Director, Division of Library Education, State University College at Geneseo.
Samuel Green's "Personal Relations between Librarians and Readers," a report on pioneer Green's Worcester library experiment in personal service to patrons. As early as in 1876 Green insisted that furnishing readers with catalogs and reference works was insufficient; instead, he advocated the need for personal guidance and interpretation of library tools to the public. Yet, the librarian's direct assistance in providing information rather than the furnishing of a source was not the most frequently cited expansion of reference services in the years following Green's recommendations. The custodial concept of librarianship was to stay in American libraries for at least one more decade, with the gradual improvement of understanding of the main function of the library as a "centre of educational influence." Professor Otis Robinson of the Rochester University library $^{2}$ went so far as to say that the library would accomplish much if it could

${ }^{2}$ Otis H. Robinson, "College Libraries as Semipublic Libraries; Rochester University Library," Library Journal, II (October 1877), 58. 
attract students and make it easy for them to do good work. In 1878, Justin Winsor of Harvard referred to the storehouse concept of libraries, preserving all the materials and discarding "nothing that is printed, no matter how trivial at the time, but may be some day in demand-helpful to significant results." ${ }^{3} \mathrm{He}$ also noted that he preferred giving a reference to a book instead of a direct answer because he wanted to inculcate the students with the habit of looking at reference books and learning how to use them intelligently. ${ }^{4}$ This concept of reference service was also supported by John Cotton Dana with a thesis that the chief duty of the library was not to answer the reference question, but to instruct the inquirer in the use of material thus enabling him to secure the answer for himself. ${ }^{5}$ In 1915 this theory was further reinforced by William Warner Bishop who contended that librarians could never master enough subject background to be of expert help to scholars. He recommended, instead, concentration upon skills in library methods. ${ }^{6}$

Charles F. McCombs also felt that the librarian should not be concerned with the study itself, "when once the books needed are identified or placed at the disposal of the reader, or with the interpretation of utilization of the facts, when once they are found or the sources of information pointed out." 7 In 1930, James I. Wyer in his Reference Work identified three distinct concepts of reference service. These he termed as "conservative," "moderate," and "liberal."

"Justin Winsor, "College and Other Higher Libraries," Library Journal, IV (November 1879), 400. "Justin Winsor, "Library Questions and Answers," Library Journal, III (June 1878), 159.

"John Cotton Dana, "Misdirection of Effort in Reference Work," Public Libraries, XVI (March 1911), 109.

"William F. Bishop, "Theory of Reference Work," Bulletin of the American Library Association, IX (July 1915), 135.

Tharles F. McCombs, The Reference Department (Chicago: American Library Association, 1929), p.2.
The earlier-mentioned theories of Dana, Bishop, and McCombs fell, according to Wyer, into the conservative class which contended that the prime function of a library is not to find answers to questions or to interpret the material to the patron, but to organize its material effectively and to teach patrons to "help themselves." Wyer, however, felt that at the time many libraries overstepped the conservative theory and approached a moderate theory, providing more than mere instruction in the use of books. Wyer did not consider this moderate theory to be adequate. He proposed a liberal theory which would "assume that every library desires to give the fullest possible attention to demands made on its service; that it will wish to find or create ways and means to satisfy every questioner. The only tenable, impregnable theory of reference is that which frankly recognizes the library's obligation to give this unlimited service."

It should be noted that since Wyer's time there have been occasional attempts to discuss the theory of reference service mainly emphasizing the degree of assistance which should be given to patrons, e.g., by Pierce Butler, Margaret Hutchins, Louis Shores, Jesse Shera, and Samuel Rothstein. Recently it has become quite evident that certain aspects of information service are also discussed by researchers in several disciplines, notably in sciences. Of interest to reference librarians are studies on intellectual processes in information storage and retrieval, information use, patterns of information exchange and informationflow channels, and many other aspects of modern concepts of information science. ${ }^{9}$

Herbert Menzel in his article on "The

${ }^{8}$ James I. Wyer, Reference Work (Chicago: American Library Association, 1930), p.11-12.

- Cf. William J. Paisley, The Flow of Behavioral Science Information. A Review of the Research Literature. (Stanford: Stanford University, Institute for Communication Research, 1966). 
Information Needs of Current Scientific Research"10 indicates three sets of assumptions that have underlain the directions of efforts toward improving science-information services in the past fifteen years.

1. The guiding slogans must be speed, efficiency and comprehensiveness. The overriding aim, in other words, is to bring information to the scientist promptly, to bring him all that is relevant, and to bring it to him with the minimum of waste motion, especially on the scientist's own part.

2. The prototype activity is exhaustive search. This means the delivery to the scientist of all documents satisfying a fairly small set of criteria that he has well defined in advance.

3 . The achievement of these goals lies along the roads of greater systematization, greater streamlining, greater mechanization of information processing and dissemination. ${ }^{11}$

It is self-evident that especially now, with the strong emphasis on the informational needs, the traditional reference role of the library should be carefully re-examined. Librarians need to evaluate their traditional "status quo" and design new methods for dissemination of information if we want to improve information service along the channels described by Menzel. The question that remains to be answered is quite simple. Are we dissatisfied with the present status; are we trying to change the content as well as the technique in library reference service?

The answer to this question can be easily illustrated by a survey of our professional literature. In order to answer some questions about the current status

${ }^{10}$ Herbert Menzel, "The Information Needs of Current Scientific Research," Library Quarterly, XXXIV (January 1964), 4-19.

11 Ibid., p.5. of reference services, an interesting survey of periodical literature was conducted by Betty Hinton, at the suggestion of this author, covering articles in library periodicals from $1954-1964 .{ }^{12} \mathrm{Sev}-$ eral questions were asked in terms of content analysis. Are the librarians and the library patrons aware of the potentialities of reference service? Are any particular aspects of reference service emphasized? Has the emphasis on any aspects of reference services changed during the period studied? Are the developments in automation being applied to reference service? Do the articles contribute meaningfully to the problems of reference? It was hypothetically assumed that: (a) periodical literature reflects trends within reference service; (b) articles are usually related to practical problems and are seldom concerned with the development of theory or definition of reference work; and (c) the majority of articles are written by reference librarians.

For the purpose of this study, reference service, which has no established definition, was considered to be any activity related to providing information, as well as guidance and instruction in the use of library resources (a necessary compromise). To obtain pertinent material seven indexes to periodical litera-

${ }^{12}$ Betty Hinton, "A Study of Articles on Reference Service, 1954-1964, Accompanied by a Selective Bibliography." Denver, 1966 (unpublished paper).

TABLE 1

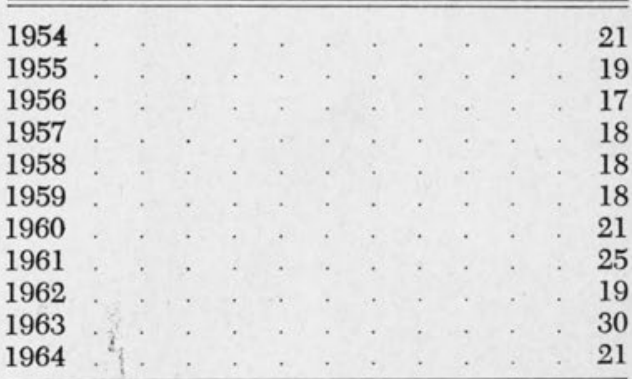


TABLE 2

SOURCES

\begin{tabular}{|c|c|c|}
\hline Name of Journal & $\begin{array}{l}\text { Number of } \\
\text { Articles }\end{array}$ & Per Cent \\
\hline Library Journal & 57 & 25.1 \\
\hline $\begin{array}{l}\text { Wilson Library Bulletin } \\
\text { College and Research }\end{array}$ & 18 & 8.0 \\
\hline Libraries & 15 & 6.6 \\
\hline Special Libraries & 15 & 6.6 \\
\hline Library Association Record & 13 & 5.7 \\
\hline Library Trends & 11 & 4.8 \\
\hline News Notes of California & & \\
\hline Libraries & 9 & 4.0 \\
\hline All Others. & 89 & 39.2 \\
\hline
\end{tabular}

ture under eighty-three subject headings were consulted..$^{13}$ There were originally 332 articles found through the indexes, but fifty-six were duplicates that appeared in two or more indexes, and forty-nine were not available or proved unrelated to the study. The 227 finally chosen occurred in fifty-four different periodicals, and it is interesting to note that the breakdown by years did not reveal a great variation in the number of articles published (Table 1). Although with the exception of Louis Shores no one writer contributed heavily to literature about reference service, several journals carried a large number of articles (Table 2). The authorship of the 227 articles had the following breakdown, as in Table 3.

It is interesting to note that reference librarians did not write the majority of articles, and out of the total of 126 articles written by practicing librarians only sixty-three were written by persons designated as reference librarians.

To determine existing trends the articles were divided into several broad categories (Tables 4 and 5).

An overview of all the articles revealed certain trends. First, we can as-

\footnotetext{
13 The indexes consulted: Reader's Guide, Public Affairs Information Service Bulletin, Library Literature, Library Science Abstracts, Social Sciences and Humanities Index, Education Index, and Monthly Catalog.
}

sume that there is some consensus on $\checkmark$ the nature of reference service in relation to public, academic, and special libraries. The type of service provided in a public library seems to meet Samuel Rothstein's definition of reference service as "the personal assistance given by the librarian to individual readers in pursuit of information." ${ }^{14}$ None of the articles disputed this definition, although comments were made that the small libraries could not accomplish even this. Academic libraries added to this definition the thought that "reference librarians are there to teach people how to use the library as well as answer specific questions." ${ }^{15}$ Special libraries gave the most extensive service of any of the libraries. Mary Anders said that the difference between reference service in special libraries and other libraries involved six factors on the part of special libraries: a lack of emphasis on teaching the use of the library, a greater participation by librarians in a search of information, the emphasis on information rather than tools, the time pressure, a better relationship between librarians and users, and the use of subject spe-

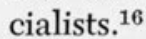

Second, as to the theory of reference, there seems to be none. Samuel Roth-

14 Samuel Rothstein, "Reference Service: The New Dimensions in Librarianship," Wilson Library Bulletin, XXXVI (January, 1963), 412.

${ }_{15}$ William H. Jesse, "Facing the Sixties: Readers" Services in the College Library," Kentucky Library Association Bulletin XXVIII (July, 1964), 17.

${ }_{10}$ Mary Edna Anders, "Reference Service in Special Libraries," Library Trends, XII (January, 1964), 390-404.

TABLE 3

AUTHORSHIP

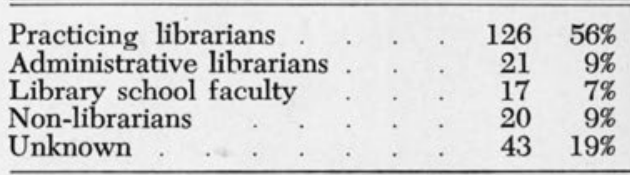


stein's two articles called for the consideration of a theory, and a few references were made in survey articles about the lack of a theory. Librarians now as fifty years ago seem unaware of a need for a theory offering, for better or worse, a description of specific operations within a given library. As a result most of the articles clustering in a rather nebulous heading "reference work and service" were repetitive of "how we do it in our library" or simply were news reports of how the library dealt with a specific problem, with no attempts at any kind of generalization.

This is true in relation to more recent developments, as for example, regional concept of reference service, or automation. It seems that if we must tolerate certain "new trends" (everybody is talking about it), we prefer to discuss them. as some sort of artificial entity which will not effect our traditional "know how."

Our psychological complex might be illustrated even in the area of library education. So, for example, not very long ago a new descriptor "information science" appeared in the titles of some library schools along with new separate programs and new degrees, emphasizing such specialization. Most library schools, however, are quite content with adding a few courses in documentation and information retrieval. But it seems that neither approach attempts to assimilate

\section{TABLE 4}

Content Analysis: Subject Breakdown

Reference libraries, special

Reference libraries, academic

Reference libraries, public

Reference librarians and training

Cooperation, regional systems

Automation

Extension of services

Statistics

Reference in relation to other

library activities

Reference work or service (general)
TABLE 5

Content Analysis: Types of Articles

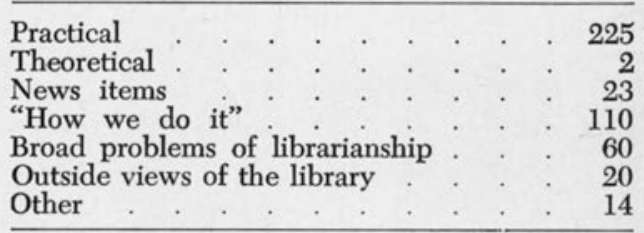

these new concepts in information handling and incorporate them in the whole spectrum of "traditional" curriculum. They often exist side by side, sometimes not even on speaking terms. In the meantime several academic programs in science engineering have started outside the library profession, producing not only computer technicians but information specialists as well. As was mentioned before, there is also a growing movement among researchers in areas other than librarianship to study general processes identified with the successful systems of scientific information exchange, that is, the generic identification and origination of information, its transmission, storage, and use. How many reference librarians, however, even discuss the impressive studies of the Project on Scientific Information Exchange in Psychology, the recent projects on information problems in linguistics, or the numerous pilot projects on scientific communication among engineers and scientists? There are even some retrospective bibliographies in this area which are probably little known to our profession. ${ }^{17}$

Many other questions can be raised. It seems that librarianship now, more than ever before, with its lack of internal coordination, is likely to tumble to the empirical ground where it will remain, and, according to some, should remain. If librarianship is to develop a theory of

${ }^{17}$ Cf. William J. Paisley, op. cit. 
reference, there first must be agreement within the profession that theory is a proper concern of librarianship. With an interdisciplinary approach there still is a hope that we can emerge from present isolation. If not, then as Neal Harlow has cleverly indicated, "Melvil Dewey's craftsman might step out of the 1880's into the present day library and do very well by reading the news-of-the-week and becoming acquainted with the recent 'titles,' that is, his point of view as a librarian would not be much out of date. He could still operate on coun- try store principles, keeping a list of everything in stock and retailing it to a regular clientele, taking care of little emergencies, and developing enough good will to keep the customer returning. $\mathrm{He}$ could even do business within a somewhat more modern concept, that of the service station, with its limited stock and routine services, and its simple objectives to keep the line of patrons moving and the operator gainfully employed."18

${ }^{18}$ Neal Harlow, "Who's Afraid of Melvil Dewey," PNLA Quarterly, XXXI (October, 1966), 14. 